\title{
Study on Anthropometric Profile of Renal Calculi Patients
}

\author{
Harmanjot Kaur ${ }^{1 *}$, Roopjot Kochar ${ }^{2}$ \\ ${ }^{1}$ Desh Bhagat University, Mandi Gobindgarh, Punjab, India \\ ${ }^{2}$ Ayurvedic Nutritionist and Administrator, SGS Ayurvedic Diet and Nutrition, Khanna, India
}

*Corresponding Author: Harmanjot Kaur, Desh Bhagat University, Mandi Gobindgarh, Punjab, India, Email:harmankochar@yahoo.co.in

\begin{abstract}
Renal Calculi is one of the most common diseases. During the past several decades, its prevalence and incidence have increased markedly in elderly population. Although 50 types of stones have been recognized based on their crystalline composition, Oxalate and phosphate calcium salts are the most frequent crystalline components of kidney stones, accounting for nearly $80 \%$ of all removed/excreted renal calculi each year. The present study was conducted on a total of 130 renal calculi patients selected randomly from Civil Hospital, Khanna, reputed private hospitals and ayurvedic medical practitioners who prescribed herbal medicines for curing ailment. Anthropometric profile of the selected patients has been studied by recording body measurements including height \& weight and calculation of BMI thereafter. The present study findings revealed that renal calculi are found more among males than females. The mean height of male renal calculi patients (161.44 $\pm 0.73 \mathrm{~cm}$ ) was significantly (at 5\% level) higher than female renal calculi patients $(159.20 \pm$ $0.63 \mathrm{~cm})$. Also, weight and body mass index of male renal calculi patients were found to be high $(60.24 \pm 0.82$ $\mathrm{kg}$ and $23.10 \pm 0.28 \mathrm{~kg} / \mathrm{m}^{2}$ respectively) than female renal calculi patients $(58.37 \pm 1.05 \mathrm{~kg}$ and $22.80 \pm 0.47$ $\mathrm{kg} / \mathrm{m}^{2}$ respectively).
\end{abstract}

Keywords: Anthropometric profile, renal calculi, BMI, Hypertensive, Urological Disorders

\section{INTRODUCTION}

Renal Calculi is one of the most painful and common disorders of the urinary tract. A large number of people are suffering from kidney stones all over the globe. Kidney stones, which are solid crystals that form from dissolved minerals in urine, along with other environmental and metabolic factors. Calcium oxalate and phosphate stones accounts for almost $70 \%$ of all renal stones observed in economically developed countries. Among the different types of kidney diseases, renal calculi are a common and a major cause of morbidity. Nearly $75-80 \%$ of renal stones are calcium containing, composed largely of calcium oxalate followed by calcium phosphate. Another 10$15 \%$ is struvite composed of magnesium ammonium and phosphate. $6 \%$ are uric acid stones and $1-2 \%$ is cysteine stones [1].

Kidney stones are quite common and usually affect people who are between 30 and 60 years of age. They affect men more than women [2]. Iran, Japan, and the United States had stone incidence reports stratified by age. Incidence rates reported by age group consistently show a rise-and-fall pattern as a population ages. Peak incidence was found between aged 40 to 49 years for all 3 countries, but for Japanese women, peak incidence occurred at aged 50 to 59 years.

The actual incidence rate was similar for men age 40 to 49 years in the United States and Japan but lower in Iran [3]. It is estimated that renal colic (severe pain caused by a kidney stones) affects about $10-20 \%$ of men, and 3-5\% of women. In India, $12 \%$ of the population is expected to have urinary stones, out of which $50 \%$ may end up with loss of kidneys or renal damage. Recurrent stone formation is a common problem with all types of stones and therefore an important part of the medical care of patients with stone disease [2].

The history of renal stones dates back to times of Egyptian mummies. They are found in $1 \%$ of all autopsies. The distribution of renal stones varies differently across the world. High incidence areas are Scandinavian countries, Mediterrenanian, British Isles, Northern Australia, and central Europe, parts of Malaysia, China, Pakistan, and Western India. In Asia the 
stone belt has been reported to stretch across Sudan, Saudi Arabia, UAE, Pakistan, India, Myanmar, Thailand, Indonesia and Philippines. In the United States, overall stone prevalence has doubled since the 1964-1972 time period, and appears to have stabilized since the early 1980s. Other countries with documented increases in prevalence include Germany, Spain, and Italy.The risk of developing renal calculi in adults appears to be higher in the western hemisphere (5-9\% in Europe, $12 \%$ in Canada, $13-15 \%$ in the USA) than in the eastern hemisphere (1-5\%), although the highest risks have been reported in some Asian countries such as Saudi Arabia (20.1\%) [1].

The incidence of urinary tract stone disease is increasing. According to the National Health and Nutrition Examination Survey, as of 2012, $10.6 \%$ of men and $7.1 \%$ of women in the United States are affected by renal stone disease, compared to just $6.3 \%$ of men and $4.1 \%$ of women that were affected in 1994. Further, within the affected population the gender gap has narrowed substantially and the incidence of stone disease in pediatric patients continues to be on the rise. Multiple studies have proposed an explanation for the evolving epidemiology of renal stone disease.

\subsection{Anthropometry and Renal Calculi}

The interplay of obesity and other components of the metabolic syndrome have been linked to stone formation through varied postulated pathophysiologies including increased urinary oxalate excretion, increased uric acid production and defects in ammoniogenesis. Hypertension as well other metabolic changes, associated with obesity may lead to the formation of stones. In a study conducted at the University of Naples a clinical association between hypertension and renal calculi has been found [4]. Specifically, the prevalence of renal calculi in treated hypertensives was found to be in $32.8 \%$ of the subjects, compared to $13.4 \%$ in the normal subjects. In a later prospective 8-year study, the incidence of kidney stone disease was found to be greater in hypertensive men with no evidence of stone disease at baseline [4]. Over the course of 8 years, $16.7 \%$ of men developed renal calculi, compared to $8.5 \%$ of normal male subjects. This suggests that hypertension is a predictor for urinary stone disease, rather than a consequence of renal damage following the development of renal calculi. Obesity has also been linked to reduction in urinary $\mathrm{pH}$ and associated renal calculi. Obesity is known to predispose to insulin resistance and diabetes. Kidney stones were more common among obese individuals than among normal-weight subjects $(11.3 \%$ vs. $6.1 \%)$. It was examined the effects of obesity on urinary $\mathrm{pH}$ and urinary stone composition [5] and reported an inverse correlation between patients' BMI and urinary $\mathrm{pH}$. Patients with higher BMI's were found to have lower urinary $\mathrm{pH}$ and higher occurrence rates of urate, calcium oxalate and calcium phosphate stones. Another study found no correlation between obesity and prevalence of calcium phosphate stones [6]. However, the percentage of uric and calcium oxalate stones was also found to be higher in obese than nonobese patients. In a study, the prevalence of calcium oxalate stones in obese patients was found to be $34.9 \%$, compared to $23.1 \%$ in patients with normal weight. Similarly, the prevalence of uric acid stones was $7.7 \%$ for the obese group and $2.8 \%$ for the normal weight group. According to another study, which looked at 27,980 calculi, collected between the years 1976 and 2001, analyzing their composition via infrared spectroscopy, found that females tend to have preponderance for calcium phosphate and struvite stones, presumably due to increased susceptibility to urinary infections [4]. The same study also found that the prevalence of uric acid stones tends to increase with age for both sexes. In a German study by the authors also found a positive inverse relationship between BMI and urinary $\mathrm{pH}$ in both genders [4]. In obese individuals there was an increase in urinary excretion of uric acid, sodium, ammonium, and phosphate. An association between obesity and an increase in urinary oxalate excretion was noted only in females, but not in the male participants of the study. Conversely, an increase in urinary calcium excretion was associated with obesity in men but was not noted in women. According to the authors, as BMI increased, there was no increase in excretion of inhibitors of stone formation, such as magnesium and citrate [4]. Being obese (higher BMI) and experiencing weight gain have each been associated with stone risk among men and women. Common dietary habits explain both obesity and kidney stones, because obese individuals are presumed more likely to eat more food and, perhaps, a less healthy mix (e.g., fewer fruits and vegetables and more red meat, or a less "DASH-like" diet) [7]. 


\section{MATERIALS AND MethodS}

The present study was conducted on a total of 130 renal calculi patients selected randomly from Civil Hospital, Khanna. Information on the patients suffering from the ailment was also collected from local reputed hospitals and Ayurvedic medical practitioners who prescribed herbal medicines for curing ailment. The data was collected through personal interview. Anthropometric measurements including height and weight were taken following the standard techniques [8] with the help of anthropometer rod and weighing balance respectively. BMI was calculated by the equation given by Garrow and Webster [9] from the recorded values of height and weight measurements of each patient.

$$
\mathrm{BMI}=\frac{\text { Weight }(\mathrm{kg})}{\operatorname{Height}^{2}(\mathrm{~m})}=\mathrm{Kg} / \mathrm{m}^{2}
$$

Nutritional status of each subject has been classified on the basis of value of calculated BMI as per WHO [9]. The collected data was quantified by using frequency tables and the percentages, standard errors and means for studying variables were calculated. The data was statistically analyzed to find out various differences and associations among variables using chi square test, correlation and t-tests.

\section{RESULTS AND DISCUSSION}

A total of 130 renal calculi patients were selected randomly from Khanna out of which 60 percent were male and 40 percent were female patients.

\subsection{Age Wise Distribution of Selected Renal Calculi Patients}

\begin{tabular}{|c|c|c|c|}
\hline Age (Years) & Male $(n=78)$ & $\begin{array}{c}\text { Female } \\
(n=52)\end{array}$ & $\begin{array}{c}\text { Total } \\
(\mathbf{N}=130)\end{array}$ \\
\hline $\begin{array}{|ll|}\leq 30 & \text { (Group } \\
\text { I) } & \\
\end{array}$ & $27(34.62)^{*}$ & $16(30.76)$ & $43(33.08)$ \\
\hline Mean \pm S.E. & $23.92 \pm 0.62$ & $24.93 \pm 0.68$ & \\
\hline \begin{tabular}{|l|}
$30-45$ \\
(Group II)
\end{tabular} & $36(46.15)$ & $24(46.16)$ & $60(46.15)$ \\
\hline Mean \pm S.E. & $37.5 \pm 0.28$ & $37.45 \pm 0.40$ & \\
\hline \begin{tabular}{|lr} 
Above & 45 \\
(Group III)
\end{tabular} & $15(19.23)$ & $12(23.08)$ & 27 (20.77) \\
\hline Mean \pm S.E. & $53.8 \pm 0.94$ & $55.08 \pm 0.97$ & \\
\hline
\end{tabular}

Table1. Age wise distribution of selected renal calculi patients

*Figures in the parentheses indicate percentages

After collection of data, the patients were further distributed into three age groups as Group I, Group II and Group III. As illustrated in the Table 1, among all patients, maximum numbers of patients i.e. 46.15 percent were in Group II, 33.08 per cent patients were in age Group I and rest 20.77 percent patients were in Group III.

The mean \pm standard error of age of male patients was found to be $23.92 \pm 0.62$, $37.50 \pm 0.28$ and $53.8 \pm 0.94$ years in the age group I, II and III, respectively.

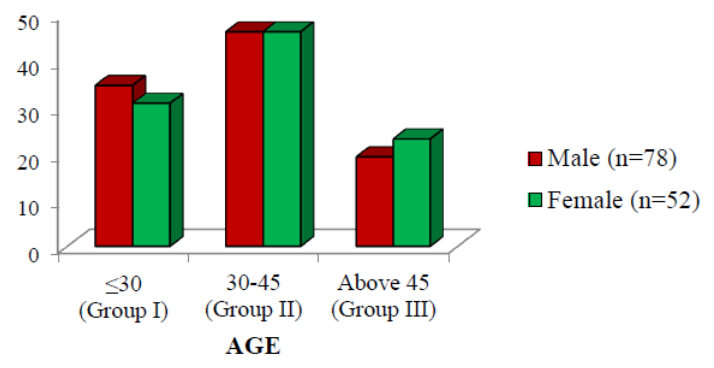

Fig1. Age wise distribution of selected renal calculi patients

Whereas the mean \pm standard error age of female patients was found to be $24.93 \pm 0.68$ years, $37.45 \pm 0.40$ and $55.08 \pm 0.97$ years in the age group I, II and III, respectively. It was found in another study that maximum number of patients i.e. $42.86 \%$ belonged to age group of 31 - 40 years, while $17.86 \%$ patients belonged to 21 -30years and $41-50$ years of age group each, and $10.71 \%$ of patients belonged to $51-60$ and above 60 years of age group [11].

Data on anthropometric measurements i.e. height, weight and BMI is presented in Table 2.

Height- Scrutiny of data (Table 2) revealed that there was a significant difference (at 5\% level) between height of male and female renal calculi patients. Majority (29.49 percent) of male patients had height ranging from $160-165 \mathrm{~cm}$ followed by $150-155 \mathrm{~cm}$ (25.64 percent), 160$170 \mathrm{~cm}$ (14.10 percent), 170-175 cm (12.82 percent), $155-160 \mathrm{~cm}$ (11.54 percent), $\leq 150 \mathrm{~cm}$ (5.13 percent) and $\geq 175 \mathrm{~cm}$ (1.28 percent). In case of female renal calculi patients, the height range in majority (38.46 percent) was 160-165 $\mathrm{cm}$, followed by $150-155 \mathrm{~cm}$ (30.77 percent), $155-160 \mathrm{~cm}$ (21.15 percent) and $165-170 \mathrm{~cm}$ (9.62 percent), respectively. Moreover, there was highly significant difference (at 5 percent level) between height of male and female renal calculi patients.

Weight- Weight of male and female renal calculi patients varied non-significantly. In case of males, majority (42.31 percent) had weight ranging from $50-60 \mathrm{~kg}$ followed by $60-70 \mathrm{~kg}$ (35.90 percent), more than $70 \mathrm{~kg} \quad(12.82$ 
percent), $40-50 \mathrm{~kg}$ (7.69 percent) and less than $40 \mathrm{~kg}$ (1.28 percent). In case of females, majority (44.23 percent) had weight in the range of $60-70 \mathrm{~kg}$ followed by $50-60 \mathrm{~kg}(36.54$ percent), $40-50 \mathrm{~kg}$ (15.38 percent) and $\geq 70 \mathrm{~kg}$ (3.85 percent).

Table2. Distribution of selected renal calculi patients on the basis of anthropometry

\begin{tabular}{|c|c|c|c|}
\hline Variables & Male $(n=78)$ & $\begin{array}{c}\text { Female } \\
(n=52)\end{array}$ & $\begin{array}{c}\text { Total } \\
(\mathrm{N}=130)\end{array}$ \\
\hline \multicolumn{4}{|l|}{$\begin{array}{l}\text { Height } \\
(\mathrm{cm})\end{array}$} \\
\hline$\leq 150$ & $4(5.13)$ & - & $4(3.08)$ \\
\hline $150-155$ & $20(25.64)$ & $16(30.77)$ & $36(27.69)$ \\
\hline $155-160$ & $9(11.54)$ & $11(21.15)$ & $20(15.38)$ \\
\hline $160-165$ & $23(29.49)$ & $20(38.46)$ & $43(33.08)$ \\
\hline $165-170$ & $11(14.10)$ & $5(9.62)$ & $16(12.31)$ \\
\hline $170-175$ & 10(12.82) & - & $10(7.69)$ \\
\hline$\geq 175$ & $1(1.28)$ & - & $1(0.77)$ \\
\hline \multicolumn{4}{|c|}{$\begin{array}{l}\chi 2=13.44 * \\
* \text { Significant at } 5 \text { per cent level }\end{array}$} \\
\hline \multicolumn{4}{|c|}{\begin{tabular}{|l|l|l|}
$\begin{array}{l}\text { Weight } \\
\text { (kg) }\end{array}$ & & \\
\end{tabular}} \\
\hline$\leq 40$ & $1(1.28)$ & 0 & $1(0.77)$ \\
\hline $40-50$ & $6(7.69)$ & $8(15.38)$ & $14(10.77)$ \\
\hline $50-60$ & $33(42.31)$ & $19(36.54)$ & $52(40.00)$ \\
\hline $60-70$ & $28(35.90)$ & $23(44.23)$ & $51(39.23)$ \\
\hline$\geq 70$ & $10(12.82)$ & $2(3.85)$ & $12(9.23)$ \\
\hline \multicolumn{4}{|c|}{$\begin{array}{l}\chi 2=5.91 \\
\text { Non-significant at } 5 \text { per cent level }\end{array}$} \\
\hline \multicolumn{4}{|c|}{\begin{tabular}{|l|l|l|}
$\begin{array}{l}\text { BMI } \\
\left(\mathrm{kg} / \mathbf{m}^{2}\right)\end{array}$ & & \\
\end{tabular}} \\
\hline$\leq 18.5$ & $7(8.97)$ & $12(23.08)$ & $19(14.62)$ \\
\hline $\begin{array}{l}18.50- \\
24.99\end{array}$ & $53(67.95)$ & $23(44.23)$ & $76(58.46)$ \\
\hline $\begin{array}{l}25.00- \\
29.99 \\
\end{array}$ & $18(23.08)$ & 17 (32.69) & $35(26.92)$ \\
\hline $30-34.99$ & - & - & - \\
\hline $\begin{array}{l}35.00- \\
39.99\end{array}$ & - & - & - \\
\hline$>40.00$ & - & - & - \\
\hline \multicolumn{4}{|c|}{$\begin{array}{l}\chi 2=8.31 * \\
* \text { Significant at } 5 \text { per cent level }\end{array}$} \\
\hline
\end{tabular}

BMI - The BMI of total 130 selected renal calculi patients when calculated came under three categories i.e. underweight, normal and overweight. There was a significant difference (at $5 \%$ level) between BMI of male and female renal calculi patients. 8.97 percent of total male and 23.08 percent of total female renal calculi patients were under underweight category with BMI of $\leq 18.5$. Majority of male and female (67.95 percent and 44.23 percent, respectively) were with normal BMI. While 23.08 percent of total male and 32.69 percent of total female renal calculi patients were under overweight category. No patient was found obese, though obesity is associated with renal calculi formation. Study reported more risk of renal calculi in patients with BMI of 30 or more. It was reported that 27.1 percent of male and 19.6 percent of female stone formers were overweight and 8.41 and 13.5 percent were obese, respectively [12].

The anthropometric measurements of selected renal calculi patients with respect to their age are presented in Table 3 .

Table3. Anthropometry of selected renal calculi patients with respect to age

\begin{tabular}{|c|c|c|c|c|}
\hline Variables & $\begin{array}{c}\text { Group I } \\
(\mathrm{M}=27) \\
(\mathrm{F}=16)\end{array}$ & $\begin{array}{c}\text { Group } \\
\text { II } \\
(M=36) \\
(\mathbf{F}=24) \\
\end{array}$ & \begin{tabular}{|c|} 
Group \\
III \\
$(\mathbf{M}=15)$ \\
$(\mathbf{F}=12)$ \\
\end{tabular} & $\begin{array}{c}\text { Mean } \\
(M=78) \\
(F=52)\end{array}$ \\
\hline \multicolumn{5}{|l|}{$\begin{array}{l}\text { Height } \\
\text { (cm) }\end{array}$} \\
\hline Male & $\begin{array}{c}162.05 \pm \\
1.28 \\
\end{array}$ & $\begin{array}{c}161.15 \pm \\
1.15 \\
\end{array}$ & $\begin{array}{c}160.68 \pm \\
1.31 \\
\end{array}$ & $\begin{array}{r}161.44 \\
\pm 0.73 \\
\end{array}$ \\
\hline Female & $\begin{array}{c}157.53 \pm \\
0.89\end{array}$ & $\begin{array}{c}159.17 \pm \\
1.13\end{array}$ & $\begin{array}{c}161.43 \pm \\
1.06\end{array}$ & $\begin{array}{l}159.20 \\
\pm 0.63\end{array}$ \\
\hline $\mathrm{t}$-value & $2.38 * *$ & 1.17 & 0.43 & $2.13^{*}$ \\
\hline \multicolumn{5}{|l|}{$\begin{array}{l}\text { Weight } \\
\text { (kg) }\end{array}$} \\
\hline Male & $\begin{array}{l}61.45 \pm \\
1.05\end{array}$ & $\begin{array}{c}59.41 \pm \\
0.46\end{array}$ & $\begin{array}{l}59.19 \pm \\
2.16 \\
\end{array}$ & $\begin{array}{c}60.24 \pm \\
0.82 \\
\end{array}$ \\
\hline Female & $\begin{array}{c}60.26 \pm \\
8.00\end{array}$ & $\begin{array}{c}57.00 \pm \\
1.74\end{array}$ & $\begin{array}{c}58.23 \pm \\
6.43\end{array}$ & $\begin{array}{c}58.37 \pm \\
1.05\end{array}$ \\
\hline $\mathrm{t}$-value & 0.59 & 1.08 & 0.33 & 1.39 \\
\hline \multicolumn{5}{|l|}{\begin{tabular}{|l|} 
BMI \\
$\left(\mathrm{kg} / \mathrm{m}^{2}\right)$
\end{tabular}} \\
\hline Male & $\begin{array}{c}23.45 \pm \\
0.42\end{array}$ & $\begin{array}{c}22.83 \pm \\
0.42\end{array}$ & $\begin{array}{c}22.89 \pm \\
0.77\end{array}$ & $\begin{array}{c}23.10 \pm \\
0.28\end{array}$ \\
\hline Female & $\begin{array}{c}24.50 \pm \\
0.71\end{array}$ & $\begin{array}{c}21.85 \pm \\
0.86\end{array}$ & $\begin{array}{c}22.33 \pm \\
0.62\end{array}$ & $\begin{array}{c}22.80 \pm \\
0.47\end{array}$ \\
\hline $\mathrm{t}$-value & 1.32 & 1.11 & 0.55 & 0.50 \\
\hline \multicolumn{5}{|c|}{ *Significant at 5 per cent level } \\
\hline \multicolumn{5}{|c|}{ ***Significant at 1 per cent level } \\
\hline \multicolumn{5}{|c|}{$\begin{array}{l}\mathrm{M}=\text { number of } \\
\mathrm{F}=\text { number of } \\
\end{array}$} \\
\hline
\end{tabular}

Height - The mean \pm standard height of the male renal calculi patients was found to be $162.05 \pm 1.28 \mathrm{~cm}, 161.15 \pm 1.15 \mathrm{~cm}$ and 160.68 $\pm 1.31 \mathrm{~cm}$ for age group I, II and III, respectively. On the other hand, mean height of female renal calculi patients was $157.53 \pm 0.89$ $\mathrm{cm}, 159.17 \pm 1.13 \mathrm{~cm}$ and $161.43 \pm 1.06 \mathrm{~cm}$ for age group I, II and III, respectively. A significant difference (at 5 per cent level) was found between mean height of male and female renal calculi patients i.e. $161.44 \pm 0.73 \mathrm{~cm}$ and $159.20 \pm 0.63 \mathrm{~cm}$, respectively.

Weight - The mean \pm standard error weight of male renal calculi patients was found to be $61.45 \pm 1.05 \mathrm{~kg}, 59.41 \pm 0.46 \mathrm{~kg}$ and $59.19 \pm$ 
$2.16 \mathrm{~kg}$ for age group I, II and III with mean weight of $60.24 \pm 0.82 \mathrm{~kg}$. While the mean, \pm standard error weight of female renal calculi patients was $60.26 \pm 8.00 \mathrm{~kg}, 57.00 \pm 1.74 \mathrm{~kg}$ and $58.23 \pm 6.43 \mathrm{~kg}$ for age group I, II and III, respectively with mean weight of $58.37 \pm 1.05$ $\mathrm{kg}$.

BMI- Body mass index of male and female renal calculi patients varied significantly (at 5 per cent level). The mean \pm standard error BMI of male renal calculi patients as calculated was $23.45 \pm 0.42 \mathrm{~kg} / \mathrm{m}^{2}, 22.83 \pm 0.42 \mathrm{~kg} / \mathrm{m}^{2}$ and $22.89 \pm 0.77 \mathrm{~kg} / \mathrm{m}^{2}$ for age group I, II and III, respectively with mean BMI of $23.10 \pm 0.28$ $\mathrm{kg} / \mathrm{m}^{2}$. The mean \pm standard error BMI of female patients was $24.50 \pm 0.71 \mathrm{~kg} / \mathrm{m}^{2}, 21.85 \pm$ $0.86 \mathrm{~kg} / \mathrm{m}^{2}$ and $22.33 \pm 0.62 \mathrm{~kg} / \mathrm{m}^{2}$ for age group I, II and III, respectively with mean BMI of $22.8 \pm 0.47 \mathrm{~kg} / \mathrm{m}^{2}$.

\section{Conclusions}

Out of total $(\mathrm{N}=130)$ renal calculi patients, 60 per cent were males and 40 percent were females. Anthropometric measurements of selected renal calculi patients revealed that majority i.e. 33.08 percent of patients had height in the range of 160- $165 \mathrm{~cm}$, weight $(40.00$ percent) in the range of $50-60 \mathrm{~kg}$ and BMI (58.46 percent) in the range of 18.5-24.99 $\mathrm{kg} / \mathrm{m}^{2}$. There was significant difference (at $5 \%$ level) between their height and BMI of renal calculi patients with respect to gender. The mean height of male renal calculi patients $(161.44 \pm 0.73 \mathrm{~cm})$ was significantly (at $5 \%$ level) higher than female renal calculi patients $(159.20 \pm 0.63 \mathrm{~cm})$. Also weight and body mass index of male renal calculi patients was also high $\left(60.24 \pm 0.82 \mathrm{~kg}\right.$ and $23.10 \pm 0.28 \mathrm{~kg} / \mathrm{m}^{2}$ respectively) than female renal calculi patients $\left(58.37 \pm 1.05 \mathrm{~kg}\right.$ and $22.80 \pm 0.47 \mathrm{~kg} / \mathrm{m}^{2}$ respectively).

\section{REFERENCES}

[1] Shamsuddeen S. B., Bano R., Shammari E. A. and Enezi S. H., Risk Factors of Renal Calculi, IOSR. J. Dentl. Med. Sciences. 11 (6), 90-95 (2013).

[2] Sofia H. N., Prevalence and risk factors of kidney stone, GJRA. 5(3), 183-187 (2016).

[3] Victoriano R., Haluk A. and Dean G. A., Kidney Stones: A Global Picture of Prevalence, Incidence, and Associated Risk Factors, Rev. Urol. 12(2-3), e86-e96 (2010).

[4] Roudakova K. and Monga M., The evolving epidemiology of stone disease, Indian. J. Urol. 30, 44-48 (2014).

[5] Najeeb Q., Masood I., Bhaskar N., Kaur H., Singh J., Pandey R., et al. Effect of BMI and urinary $\mathrm{pH}$ on urolithiasis and its composition, Saudi. J. Kidney. Dis. Transpl. 24, 60-66 (2013).

[6] Chou Y. H., Su C. M., Li C. C., Liu C. C., Liu M. E., Wu W. J., et al. Difference in urinary stone components between obese and non-obese patients, Urol. Res. 39, 283-287 (2011).

[7] Lieske J. C., New Insights Regarding the Interrelationship of Obesity, Diet, Physical Activity, and Kidney Stones, J. Am. Soc. Nephrol. 25, 207-215 (2014).

[8] Jellife D. B., The assessment of nutritional status of community, WHO Monograph Series 53, Geneva. Inc. p. 50 (1966).

[9] Garrow J. S. and Webster J., Quetelets index $(\mathrm{W} / \mathrm{H} 2)$ as a measure of fatness. Int. J. Obes. 9(2), 147-153 (1985).

[10] WHO, Obesity: Preventing and Managing the Global Epidemic: Report of WHO, Consultation on Obesity, Geneva. Inc. p 9 (2004).

[11] Chakradhar K. V., A Comparative Clinical Study on Renal Calculi -An Ayurvedic Perspective, IOSR. J. Dentl. Med. Sciences. 2 (5), 21-32 (2012).

[12] Sinha T., Karan S. C. and Kotwal A., Increased urinary uric acid excretion: A finding in Indian stone formers, Urol. Res. 38(1), 17-20 (2009).

Citation: Harmanjot Kaur, Roopjot Kochar. Study on Anthropometric Profile of Renal Calculi Patients.ARC Journal of Nutrition and Growth.2018;4(2):10-14. DOI: dx.doi.org/10.20431/2455-2550.0402003.

Copyright: (c) 2018 Authors. This is an open-access article distributed under the terms of the Creative Commons Attribution License, which permits unrestricted use, distribution, and reproduction in any medium, provided the original author and source are credited. 